\title{
Milk coagulation traits and cheese yields of purebred Holsteins and 4 generations of 3-breed rotational crossbred cows from Viking Red, Montbéliarde, and Holstein bulls
}

S. Saha, N. Amalfitano, G. Bittante, (1) and L. Gallo*

Department of Agronomy, Food, Natural Resources, Animals and Environment (DAFNAE), University of Padova, Viale dell'Università 16, 35020 Legnaro, Padova, Italy

\begin{abstract}
Crossbreeding is a strategy to counter the declining fertility, resilience, and longevity of purebred Holstein (Ho) cows. However, little is known of the effects of long-term systematic rotational crossbreeding on milk technological properties and cheese yield (CY). In this study, we compared the individual milk composition, milk coagulation properties (MCP), and CY of 468 purebred Ho and 648 crossbred (CR) cows obtained from two 3-breed rotational crossbreeding systems using Viking Red (VR), Montbéliarde (Mo), and Ho sires over 4 generations. Individual milk samples were collected once from 1,116 primiparous and multiparous cows kept in 2 dairy herds, raised for the production of Grana Padano (high milk yield, total mixed ration based on corn silage) and Parmigiano Reggiano (moderate milk yield, only dry feeds) cheeses. In both herds, a 3-breed rotational mating system was used in which Ho cows were first inseminated with VR, whereas Mo and Ho semen was used in the subsequent generations. In one herd, the sequence Mo-VR-Ho was also used. Individual milk samples were analyzed for milk composition, single-point MCP, and parameters for modeling curd firming over time, whereas $\mathrm{CY}$ and milk nutrient recovery in the curd were assessed through a laboratory cheese-making procedure. Compared with Ho, CR cows produced $5.8 \%$ less milk, which had comparable fat but greater protein and casein contents and lower lactose contents and somatic cell scores. Milk from CR cows tended to reach a curd firmness of $20 \mathrm{~mm}$ more quickly and exhibited greater curd firmness at 45 and $60 \mathrm{~min}$ from rennet addition. Holstein and CR cows yielded milk with similar $\mathrm{CY}$ and recovery in the curd traits. The milk fat content, somatic cell scores, curd firmness traits, and $\mathrm{CY}$ of $\mathrm{CR}$ cows relative to the Ho cows
\end{abstract}

Received September 11, 2019.

Accepted November 27, 2019.

*Corresponding author: luigi.gallo@unipd.it differed in the 2 herds, and the favorable effects on the CR cows were more evident in the herd with the greatest milk yield and the worst MCP traits. Crossbred cows of the 4 generations performed similarly, with the exception of the better MCP of the milk from firstgeneration CR cows. The 2 rotational systems using different sire-breed sequences also performed similarly. In summary, both rotational crossbreeding programs exhibited some advantage over the Ho purebred breeding system in terms of milk composition and MCP but not CY. Future research is needed to investigate the interactions between crossbreeding schemes and dairy systems.

Key words: dairy cow, crossbreeding, milk quality, cheese-making efficiency

\section{INTRODUCTION}

Interest in crossbreeding for commercial dairy production has been growing due to the deterioration in fertility, health, and longevity of purebred Holstein cows, the increasing rate of inbreeding in major dairy breeds (Buckley et al., 2014), and changes in milk pricing toward a focus on fat and protein contents (Weigel and Barlass, 2003; Shonka-Martin et al., 2019b). Holstein (Ho) is the major dairy breed worldwide because of its ability to produce a high volume of milk (Blöttner et al., 2011). However, greatly increased milk production and unfavorable phenotypic correlations led to the cows being less fertile, being more prone to health problems, and having lower longevity (Berry, 2018) despite the recent emphasis on improving fertility and health traits (VanRaden et al., 2018). Interest has therefore grown in crossing Ho cows with other breeds to compensate for these adverse effects. A 3-breed rotational crossbreeding program is currently gaining attention, particularly in intensive dairy systems with little opportunity for grazing (Dechow and Hansen, 2017). This type of program often involves the Montbéliarde (Mo) and Viking Red (VR) breeds, the latter including the Swedish Red, Finnish Ayrshire, and Danish Red subpopulations 
(Shonka-Martin et al., 2019b), whereas the Jersey breed seems more suited for crossbreeding programs aimed at grazing systems (Vance et al., 2012).

Crossbreeding is now widespread in many countries. For example, in 2015 crossbred cows accounted for around $50 \%$ of dairy cattle born in New Zealand (LIC, 2018). There has been a 9-fold increase in crossbred cows over the last decade in the United States (Hazel et al., 2017b), and they now account for 8 and $12 \%$ of the overall cattle population in Sweden and Denmark, respectively (Clasen et al., 2019). Most of the previous studies on crossbreeding in dairy cattle have focused on fertility (Malchiodi et al., 2014a; Hazel et al., 2017a), survivability (Hazel et al., 2014), body traits (Blöttner et al., 2011; Saha et al., 2018), and milk yield and quality (Hazel et al., 2017b).

Cheese is consistently the major dairy product worldwide. More than $36 \%$ of milk is processed into cheese products, a proportion that has increased by $23 \%$ in the last decade (International Dairy Federation, 2016). Cheese production is also the main use of milk in many European countries, such as Italy, where $75 \%$ of milk is destined for cheese production and $55 \%$ of the total milk supply is processed into Protected Designation of Origin (PDO) cheeses. The technological and cheesemaking properties of milk are increasingly critical traits for the dairy industry because milk quality is related to optimal cheese yield and quality (Malacarne et al., 2006; Skeie, 2007). However, the technological properties of milk from crossbred cows have so far received little attention. In one of few studies, Malchiodi et al. (2014b) compared the milk coagulation properties (MCP) of purebred Ho and 2 generations of crossbred cows obtained from Ho, VR, Mo, and Brown Swiss breeds in one dairy system. Cheese-making properties and milk nutrient recovery in cheese have not yet been investigated.

Focusing on the yield, composition, coagulation properties, and cheese yield (CY) of milk, the aims of this study were (1) to compare purebred Ho with 3 generations of crossbred cows obtained from a 3-breed rotational crossbreeding system using VR, Mo, and Ho sires and (2) to compare 4 different generations of crossbred cows obtained from two 3-breed rotational crossbreeding systems differing in their sire-breed sequences (VR-Mo-Ho and Mo-VR-Ho).

\section{MATERIALS AND METHODS}

\section{Herds, Animals, and Crossbreeding Programs}

The study involved 1,116 dairy cows from 2 dairy herds located in northern Italy. The crossbred cows were obtained from a 3-breed rotational crossbreeding system named ProCross, which is managed by Coopex Montbéliarde (Roulans, France) and Viking Genetics (Randers, Denmark). Both farms (Table 1) used the VR-Mo-Ho sequence: VR semen was used on Ho purebred cows to produce the first generation $\left(\mathbf{F}_{1}\right)$ of $\mathrm{VR} \times$ Ho crossbred cows, Mo semen was used on the $\mathrm{F}_{1}$ cows to produce the second generation $\left(\mathbf{F}_{2}\right)$ of $\mathrm{Mo} \times(\mathrm{VR}$ $\times$ Ho) crossbred cows, and Ho semen was used on the $\mathrm{F}_{2}$ cows to produce the third generation $\left(\mathbf{F}_{\mathbf{3}}\right)$ of Ho $\times$ $[\mathrm{Mo} \times(\mathrm{VR} \times \mathrm{Ho})]$ crossbred cows. The sequence then started again with VR and so on. In herd B, however, a second crossbreeding program was also used in which VR and Mo were reversed in the sequence (Mo-VRHo): Mo semen was used on the Ho cows to produce the $\mathrm{F}_{1}$ Mo $\times$ Ho, which were inseminated with $\mathrm{VR}$ semen to produce the $\mathrm{F}_{2}$ crossbred cows, which were inseminated with Ho semen to produce the $\mathrm{F}_{3}$ crossbred cows. The sequence was then repeated using Mo sires to obtain the fourth generation $\left(\mathbf{F}_{4}\right)$ of crossbred cows, and so on (Table 1). At least one-third of the cows in both herds were maintained as purebred Ho. Both farms were increasing the number of crossbred cows produced from purebred $\mathrm{Ho}$, and new $\mathrm{F}_{1}$ cows were obtained every year; therefore, cows of every generation and parity were present on the farms at the same time, and only the $\mathrm{F}_{4}$ cows were of on average younger age than the other crossbreds.

Only semen from bulls registered in the herd books was used for AI. Overall, 133 Ho bulls were used as sires of purebred and $\mathrm{F}_{3}$ crossbred cows (on average 5.2

Table 1. Rotational crossbreeding sequences and number of cows sampled for milk yield, composition, and technological properties for different herds and data sets

\begin{tabular}{|c|c|c|c|c|}
\hline \multirow[b]{2}{*}{ Breed combination $^{1}$} & \multicolumn{2}{|c|}{ Herd } & \multicolumn{2}{|c|}{ Data set $^{2}$} \\
\hline & $\mathrm{A}$ & $\mathrm{B}$ & 1 & 2 \\
\hline Purebred Ho & 195 & 273 & 468 & \\
\hline \multicolumn{5}{|l|}{ 3-breed rotational VR-Mo-Ho } \\
\hline $\mathrm{VR} \times \mathrm{Ho}\left(\mathrm{F}_{1}\right)$ & 35 & 47 & 82 & 47 \\
\hline $\mathrm{Mo} \times(\mathrm{VR} \times \mathrm{Ho})\left(\mathrm{F}_{2}\right)$ & 42 & 53 & 95 & 53 \\
\hline $\mathrm{Ho} \times[\mathrm{Mo} \times(\mathrm{VR} \times \mathrm{Ho})]\left(\mathrm{F}_{3}\right)$ & 48 & 137 & 185 & 137 \\
\hline $\mathrm{VR} \times\{\mathrm{Ho} \times[\mathrm{Mo} \times(\mathrm{VR} \times \mathrm{Ho})]\}\left(\mathrm{F}_{4}\right)$ & & 60 & & 60 \\
\hline \multicolumn{5}{|l|}{ 3-breed rotational Mo-VR-Ho } \\
\hline Mo $\times$ Ho $\left(F_{1}\right)$ & & 105 & & 105 \\
\hline $\mathrm{VR} \times(\mathrm{Mo} \times \mathrm{Ho})\left(\mathrm{F}_{2}\right)$ & & 71 & & 71 \\
\hline Ho $\times[\mathrm{VR} \times(\mathrm{Mo} \times \mathrm{Ho})]\left(\mathrm{F}_{3}\right)$ & & 39 & & 39 \\
\hline $\mathrm{Mo} \times\{\mathrm{Ho} \times[\mathrm{VR} \times(\mathrm{Mo} \times \mathrm{Ho})]\}\left(\mathrm{F}_{4}\right)$ & & 11 & & 11 \\
\hline Total & 320 & 796 & 830 & 523 \\
\hline
\end{tabular}

${ }^{1} \mathrm{Ho}=$ Holstein; $\mathrm{VR}=$ Viking Red $\mathrm{Mo}=$ Montbéliarde. $\mathrm{F}_{1}, \mathrm{~F}_{2}, \mathrm{~F}_{3}$, and $\mathrm{F}_{4}=$ first, second, third, and fourth generation, respectively.

${ }^{2}$ Data set $1=$ all purebred Ho and 3 generations of 3 -breed rotational (VR-Mo-Ho) crossbred cows from herds A and B. Data set $2=4$ generations of two 3-breed rotational (VR-Mo-Ho and Mo-VR-Ho) crossbred cows from herd B only. 
cows/sire), and 19 VR bulls (on average 11.2 cows/sire) and 25 Mo bulls (on average 8.4 cows/sire) were used as sires of the $\mathrm{F}_{1}, \mathrm{~F}_{2}$, and $\mathrm{F}_{4}$ crossbred cows.

Both herds, which were representative of the 2 most important dairy systems in Italy, kept cows in freestalls with cubicles and fed cows TMR. Herd A was located on the Lombardia plains (province of Brescia), in the Grana Padano PDO hard-cheese production area, and its rations were accordingly based mainly on corn silage, sorghum silage, and concentrates. Herd B was located in the Emilia-Romagna region (province of Modena), in the Parmigiano Reggiano PDO hard-cheese production area. As the regulations governing production of this cheese forbid the use of silages, cows kept in herd $\mathrm{B}$ were fed a ration based on dry roughage, mainly alfalfa and meadow hay, and concentrates. Within each herd, purebred Ho and crossbred cows were raised and milked together and were fed the same diets.

\section{Milk Sampling and Milk Yield and Composition}

Individual milk samples $(100 \mathrm{~mL})$ were collected once from all cows in 1 milk recording sampling session per herd during a winter evening milking. After collection, one aliquot of the milk sample was transferred to the laboratory of the breeders association for milk fat and protein content analysis in the context of official milk recording, whereas another aliquot of milk (without preservative) was immediately stored in a refrigerator at $-20^{\circ} \mathrm{C}$ and transferred to the Milk Quality Laboratory of the Department of Agronomy, Food, Natural Resources, Animals and the Environment of the University of Padova (Italy).

Milk yield and milk fat and protein contents of milk at the date of milk recording were obtained from the official Italian recording system (Milkoscan FT6000 infrared analyzer; Foss Electric A/S, Hillerød, Denmark). After the frozen milk samples were thawed overnight in a refrigerator at $4^{\circ} \mathrm{C}$ in random groups of 30 samples/d, casein, lactose, and TS contents were measured with a Milkoscan FT2 infrared analyzer (Foss Electric A/S). Milk pH was measured using a Crison Basic 25 electrode (Crison Instruments SA, Barcelona, Spain). Somatic cell count was obtained using a Fossomatic Minor FC counter (Foss Electric A/S) and was then converted to SCS using the log-transformation proposed by Ali and Shook (1980).

\section{Milk Coagulation and Curd Firmness Properties}

On the same thawed aliquots, curd firmness was assessed in duplicate for each cow every $15 \mathrm{~s}$ for $60 \mathrm{~min}$ (240 measures from each milk sample and each rep- licate) using a lactodynamograph (Formagraph; Foss Electric A/S) and according to the procedure described by Stocco et al. (2017). An aliquot of $10 \mathrm{~mL}$ of thawed milk was heated to $35^{\circ} \mathrm{C}$ and then mixed with $200 \mu \mathrm{L}$ of rennet solution (Hansen Standard 215 with $80 \pm 5 \%$ chymosin and $20 \pm 5 \%$ pepsin; Pacovis Amrein AG, Bern, Switzerland) diluted to $1.2 \%$ (wt/vol) with distilled water. Traditional single-point MCP traits were obtained from the lactodynamograph; namely, rennet coagulation time (RCT; min), defined as the time from rennet addition to milk gelation; curd firming time $\left(\mathbf{k}_{\mathbf{2 0}} ; \min \right)$, defined as the time taken from gelation to reach a curd firmness of $20 \mathrm{~mm}$; and curd firmness (mm) 30, 45, and 60 min after rennet addition. In addition, all 240 curd firmness records from each milk sample and replicate were modeled using the equation proposed by Bittante et al. (2013) to provide estimates of the following individual curd firming and syneresis parameters: RCT estimated from the individual curd firming equations $\left(\mathbf{R C T}_{\mathbf{e q}}\right.$; min), curd firming instant rate constant $\left(\mathbf{k}_{\mathbf{C F}} ; \% / \mathrm{min}\right)$, curd syneresis instant rate constant $\left(\mathbf{k}_{\mathbf{S R}} ; \% / \mathrm{min}\right)$, maximum curd firmness value $\left(\mathbf{C F}_{\max } ; \mathrm{mm}\right)$, and time to $\mathrm{CF}_{\max }(\min )$.

\section{Cheese-Making Procedure and CY Traits}

We used the 9-MilCA method proposed by CipolatGotet et al. (2016) to assess in duplicate on each sample CY and milk nutrient recovery in the curd. Each milk sample $(9 \mathrm{~mL})$ was poured into a glass tube, placed in a sample rack, heated at $35^{\circ} \mathrm{C}$ for $15 \mathrm{~min}$, and then gently mixed with $0.2 \mathrm{~mL}$ of rennet solution (Hansen Standard 215 , with $80 \pm 5 \%$ chymosin and $20 \pm 5 \%$ pepsin; Pacovis Amrein AG) diluted to $1.2 \%$ (wt/vol) with distilled water. After $30 \mathrm{~min}$ at $35^{\circ} \mathrm{C}$, samples were manually cut with a stainless steel spatula and then heated at $55^{\circ} \mathrm{C}$ for $30 \mathrm{~min}$ (curd cooking phase). At $15 \mathrm{~min}$ (the middle of this phase), each sample was manually cut. At the end of cooking, each glass tube was removed from the sample rack. The curd was separated from the whey for 30 min at room temperature and then lightly pressed with the same spatula used for cutting the curd to expel the whey. The resulting whey and curd were weighed using precision scales. The whey drained from the curd was analyzed for fat, protein, and TS contents using an infrared spectrophotometer (Milkoscan FT2; Foss Electric). We determined $3 \mathrm{CY}$ traits $\left(\mathbf{C Y}_{\text {curd }}, \mathrm{CY}_{\text {solids, }}\right.$ and $\mathrm{CY}_{\text {water }}$; expressing, respectively, the weight of the fresh curd, curd solids, and curd water as a percentage of the milk processed) and 2 milk nutrient recovery in the curd (REC) traits $\left(\mathbf{R E C}\right.$ protein and $\left.\mathbf{R E C}_{\text {fat }}, \%\right)$ from the differences in weight and composition between the milk and the whey (Cipolat-Gotet et al., 2016). 


\section{Editing Procedures and Statistical Analysis}

Replicated measures of the same trait were averaged before statistical analysis to obtain 1 record per cow for all traits of concern. All records were classified for parity ( 3 classes: 1,2 , and $\geq 3$ ), DIM ( 5 classes: $<60,60-120,121-180,181-240$, and $>240 \mathrm{~d})$, herd $(2$ classes: A and B), date of sample analysis (39 classes), and breed combinations (9 classes: purebred Ho; VR $\times$ Ho $\mathrm{F}_{1}$ crossbred; Mo $\times$ Ho $\mathrm{F}_{1}$ crossbred; $\mathrm{Mo} \times(\mathrm{VR} \times$ Ho) $\mathrm{F}_{2}$ crossbred; VR $\times(\mathrm{Mo} \times \mathrm{Ho}) \mathrm{F}_{2}$ crossbred; Ho $\times[\mathrm{Mo} \times(\mathrm{VR} \times \mathrm{Ho})] \mathrm{F}_{3}$ crossbred, $\mathrm{Ho} \times[\mathrm{VR} \times(\mathrm{Mo}$ $\times \mathrm{Ho})] \mathrm{F}_{3}$ crossbred; $\mathrm{VR} \times\{\mathrm{Ho} \times[\mathrm{Mo} \times(\mathrm{VR} \times \mathrm{Ho})]\}$ $\mathrm{F}_{4}$ crossbred, and $\mathrm{Mo} \times\{\mathrm{Ho} \times[\mathrm{VR} \times(\mathrm{Mo} \times \mathrm{Ho})]\} \mathrm{F}_{4}$ crossbred). The number of cows per breed combination is given in Table 1 . We compiled 2 data sets from the data, the descriptive statistics of which are given in Supplemental Table S1 (https://doi.org/10.3168/jds .2019-17576).

Data Set 1. This data set included the data from all purebred $\mathrm{Ho}$ and from $\mathrm{F}_{1}, \mathrm{~F}_{2}$, and $\mathrm{F}_{3}$ crossbred combinations from the rotational sequence VR-Mo-Ho used in both herds (830 cows; Table 1). We used the generalized linear model procedure of SAS (SAS Institute Inc., Cary, NC) to analyze the milk yield and milk fat and protein contents, including the fixed effects of herd, parity, DIM, breed, and the herd $\times$ breed interaction. We analyzed all the other traits using a mixed model procedure, which included the random effect of date of sample analysis nested within herd and the fixed effects of herd, parity, DIM, breed, and the herd $\times$ breed interaction. Orthogonal contrasts were estimated between the least squares means (LSM) of the breed combinations to compare the performance of purebred Ho with the average performance of crossbred cows and between the LSM of the herd $\times$ breed interaction to assess possible differences between the 2 herds in the comparison of Ho and crossbred cows.

Data Set 2. This data set included the data from all of the $\mathrm{F}_{1}, \mathrm{~F}_{2}, \mathrm{~F}_{3}$, and $\mathrm{F}_{4}$ crossbred cows in herd $\mathrm{B}$ produced from the 2 rotational sequences (523 cows; Table 1). We used the generalized linear model procedure of SAS to analyze the milk yield and milk fat and protein contents, including the fixed effects of parity, DIM, and breed. We analyzed all the other traits using a mixed model procedure, which included the random effect of date of sample analysis and the fixed effects of parity, DIM, and breed. Orthogonal contrasts were estimated between the LSM of the breed combinations to (1) compare the performances of the 2 rotational crossbreeding sequences, VR-Mo-Ho and Mo-VR-Ho; (2) compare the performance of the different generations $\left[\mathrm{F}_{1}\right.$ vs. $\left(\mathrm{F}_{2}+\mathrm{F}_{3}+\mathrm{F}_{4}\right) ; \mathrm{F}_{2}$ vs. $\left(\mathrm{F}_{3}+\mathrm{F}_{4}\right) ; \mathrm{F}_{3}$ vs.
$\left.\mathrm{F}_{4}\right]$; and (3) compare the performance of the crosses obtained from the 2 rotational sequences within generation $\left(\mathrm{VR} \times\right.$ Ho vs. Mo $\times$ Ho within $\mathrm{F}_{1}$; Mo $\times(\mathrm{VR} \times$ $\mathrm{Ho})$ vs. $\mathrm{VR} \times(\mathrm{Mo} \times \mathrm{Ho})$ within $\mathrm{F}_{2} ; \mathrm{Ho} \times[\mathrm{Mo} \times(\mathrm{VR}$ $\times \mathrm{Ho})]$ vs. $\mathrm{Ho} \times[\mathrm{VR} \times(\mathrm{Mo} \times \mathrm{Ho})]$ within $\mathrm{F}_{3}$; and $\mathrm{VR}$ $\times\{\mathrm{Ho} \times[\mathrm{Mo} \times(\mathrm{VR} \times \mathrm{Ho})]\}$ vs. Mo $\times\{\mathrm{Ho} \times[\mathrm{VR} \times$ $(\mathrm{Mo} \times \mathrm{Ho})]\}$ within $\left.\mathrm{F}_{4}\right)$.

\section{RESULTS}

\section{Comparison Between Purebred Ho and Crossbred Cows (Data Set 1)}

Milk Yield and Composition. The herds differed significantly with regard to milk yield and composition (Table 2). The cows from herd A (Grana Padano dairy system using silages) produced almost $4 \mathrm{~kg}$ more milk/d $(+12 \%)$ than the cows from herd B (Parmigiano-Reggiano dairy system using only dry feeds), but the milk had a lower protein content $(-3 \%)$. Breed combination also significantly affected the milk yield and composition traits. On average, purebred Ho yielded almost $35 \mathrm{~kg}$ of milk/d, $5.8 \%$ more than the crossbred cows, which yielded almost $33 \mathrm{~kg}$ of milk/d $(P<0.01)$. Milk from the crossbred cows had a fat content comparable with the milk from Ho cows but greater protein and casein contents and lower lactose contents and SCS ( $P$ $<0.01)$. The fat and lactose contents and SCS of the crossbred cows relative to the purebred Ho cows differed in the 2 herds $(P<0.05)$ : the milk from crossbred cows had an almost $4 \%$ greater fat content than the milk from purebred Ho in herd A, but fat content was almost the same in milk from crossbred and purebred Ho cows in herd B. Similarly, SCS was $20 \%$ lower in milk from crossbred cows than in milk from purebred Ho cows in herd A but only $2 \%$ lower in herd B (Figure 1).

Single-Point MCP and Curd Firming Equation Parameters. The LSM of single-point MCP across herds and breeds are reported in Table 3. On average, the samples coagulated about 24 min after rennet addition (RCT) and reached a curd firmness of $20 \mathrm{~mm}\left(\mathrm{k}_{20}\right)$ after almost $6 \mathrm{~min}$. Average curd firmness at $30 \mathrm{~min}$ was around $31 \mathrm{~mm}$ and increased to $36 \mathrm{~mm}$ at $45 \mathrm{~min}$ from rennet addition. The incidence of noncoagulating samples was comparable in purebred Ho and crossbred cows and was close to 20,6 , and $4 \%$ at 30,45 , and $60 \mathrm{~min}$ from rennet addition, respectively (data not shown). The coagulation properties of milk were significantly affected by both herd and breed effects, but the magnitude of differences in the MCP of purebred Ho relative to the crossbred cows was also different in the 2 herds. Generally, milk from the crossbred cows had 


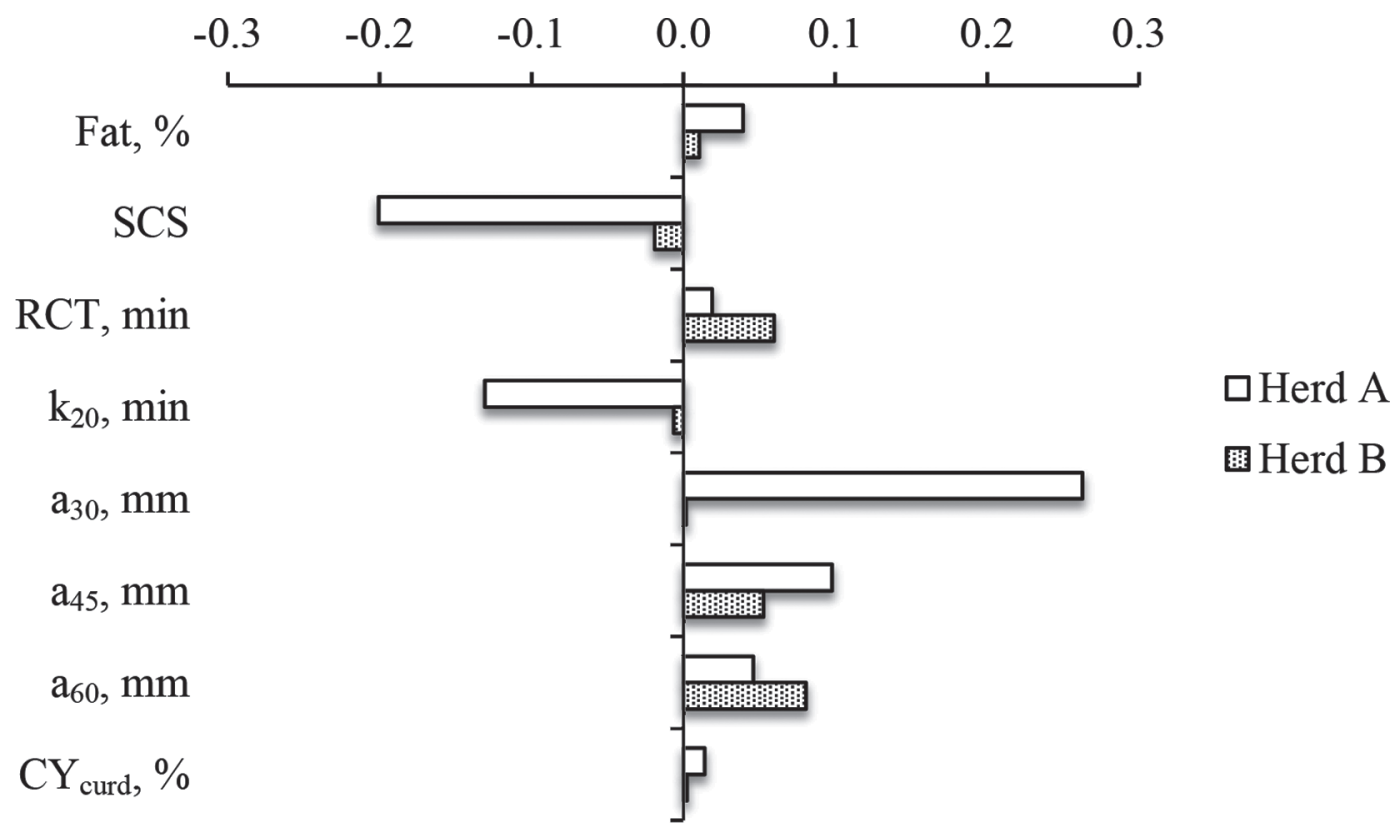

Figure 1. Least squares means of crossbred cows, expressed as the deviation from the LSM of Holstein cows, shown separately for the 2 herds for traits with a significant $(P<0.05)$ interaction between herd and breed (data set 1$)$. RCT $=$ measured rennet coagulation time; $\mathrm{k}_{20}=$ time interval between gelation and attainment of curd firmness of $20 \mathrm{~mm} ; \mathrm{a}_{30}, \mathrm{a}_{45}$, and $\mathrm{a}_{60}=$ curd firmness after 30,45 , and $60 \mathrm{~min}$ from rennet addition, respectively; $\mathrm{CY}_{\text {curd }}=$ fresh cheese yield.

similar RCT compared with milk from the purebred Ho but took less time to reach a curd firmness of $20 \mathrm{~mm}$ $\left(\mathrm{k}_{20}\right)$ and had a greater curd firmness at 30, 45, and 60 min from rennet addition. The MCP of purebred Ho cows relative to the crossbred cows also differed in the 2 herds: the milk from crossbred and Ho cows in herd A had similar RCT, whereas in herd B the milk from Ho cows had a slightly shorter RCT. Moreover, $\mathrm{k}_{20}$ and curd firmness 30 min after rennet addition were much better in milk from crossbred cows than in milk from purebred Ho cows in herd A but were similar in purebred and crossbred cows in herd B (Figure 1).

The LSM of the curd firming equation parameters across herds and breeds are reported in Table 4. The average coagulation time of each milk sample calculated on the basis of all 240 data points $\left(\mathrm{RCT}_{\text {eq }}\right)$ was 24

Table 2. Comparison between purebred Holsteins and 3 generations of 3-breed rotational (VR-Mo-Ho) crossbred cows from herds A and B (data set 1): LSM and SEM for milk yield (MY), milk nutrient contents, and SCS

\begin{tabular}{|c|c|c|c|c|c|c|c|}
\hline Item & Cows, no. & $\mathrm{MY}, \mathrm{kg} / \mathrm{d}$ & Fat, $\%$ & Protein, \% & Casein, \% & Lactose, \% & $\mathrm{SCS}^{1}$ \\
\hline A & 320 & $35.4^{\mathrm{a}}$ & 3.94 & $3.63^{\mathrm{b}}$ & $2.87^{\mathrm{b}}$ & 5.06 & 2.75 \\
\hline $\mathrm{B}$ & 510 & $31.4^{\mathrm{b}}$ & 3.81 & $3.73^{\mathrm{a}}$ & $3.02^{\mathrm{a}}$ & 5.03 & 2.59 \\
\hline \multicolumn{8}{|l|}{ Breed combination $^{2}$} \\
\hline Purebred Ho & 468 & 34.9 & 3.80 & 3.63 & 2.89 & 5.08 & 2.93 \\
\hline $\mathrm{VR} \times \mathrm{Ho}\left(\mathrm{F}_{1}\right)$ & 82 & 33.3 & 4.02 & 3.74 & 3.00 & 5.01 & 2.74 \\
\hline SEM & - & 0.7 & 0.07 & 0.03 & 0.02 & 0.02 & 0.14 \\
\hline Breed effect ( $P$-value) & - & 0.01 & 0.13 & 0.004 & 0.002 & 0.0007 & 0.008 \\
\hline \multicolumn{8}{|l|}{ Contrast ( $P$-value) } \\
\hline Ho vs. crossbreds $\left(F_{1}+F_{2}+F_{3}\right)$ & - & 0.002 & 0.14 & 0.01 & 0.0008 & 0.0002 & 0.003 \\
\hline (Ho vs. crossbreds) $\times$ herd & - & 0.37 & 0.05 & 0.21 & 0.38 & 0.01 & 0.03 \\
\hline
\end{tabular}

${ }_{\mathrm{a}, \mathrm{b}}$ Least squares means across columns with different superscripts are significantly different $(P<0.05)$.

${ }^{1} \mathrm{SCS}=3+\log _{2}(\mathrm{SCC} / 100,000)$.

${ }^{2} \mathrm{Ho}=$ Holstein; $\mathrm{VR}=$ Viking Red; Mo = Montbéliarde. $\mathrm{F}_{1}, \mathrm{~F}_{2}, \mathrm{~F}_{3}$, and $\mathrm{F}_{4}=$ first, second, third, and fourth generation, respectively. 
Table 3. Comparison between purebred Holsteins and 3 generations of 3-breed rotational (VR-Mo-Ho) crossbred cows from herds A and B (data set 1): LSM and SEM for single-point milk coagulation properties

\begin{tabular}{|c|c|c|c|c|c|c|}
\hline \multirow[b]{2}{*}{ Item } & \multirow[b]{2}{*}{ Cows, no. } & \multicolumn{5}{|c|}{ Milk coagulation property ${ }^{1}$} \\
\hline & & $\mathrm{RCT}, \min$ & $\mathrm{k}_{20}, \min$ & $\mathrm{a}_{30}, \mathrm{~mm}$ & $\mathrm{a}_{45}, \mathrm{~mm}$ & $\mathrm{a}_{60}, \mathrm{~mm}$ \\
\hline \multicolumn{7}{|l|}{ Herd } \\
\hline A & 320 & $31.7^{\mathrm{a}}$ & $8.5^{\mathrm{a}}$ & $19.9^{\mathrm{b}}$ & $26.7^{\mathrm{b}}$ & $25.9^{\mathrm{b}}$ \\
\hline B & 508 & $19.9^{\mathrm{b}}$ & $4.7^{\mathrm{b}}$ & $35.8^{\mathrm{a}}$ & $41.8^{\mathrm{a}}$ & $39.6^{\mathrm{a}}$ \\
\hline SEM & - & 0.7 & 0.3 & 1.5 & 1.4 & 1.6 \\
\hline \multicolumn{7}{|l|}{ Breed combination $^{2}$} \\
\hline Purebred Но & 467 & 25.2 & 7.1 & 26.2 & 32.5 & 31.2 \\
\hline $\mathrm{VR} \times \operatorname{Ho}\left(\mathrm{F}_{1}\right)$ & 82 & 27.1 & 6.6 & 31.9 & 33.8 & 31.7 \\
\hline $\mathrm{Mo} \times(\mathrm{VR} \times \mathrm{Ho})\left(\mathrm{F}_{2}\right)$ & 95 & 26.3 & 6.8 & 24.1 & 33.7 & 33.1 \\
\hline $\mathrm{Ho} \times[\mathrm{Mo} \times(\mathrm{VR} \times \mathrm{Ho})]\left(\mathrm{F}_{3}\right)$ & 184 & 24.6 & 5.9 & 29.2 & 37.0 & 34.8 \\
\hline SEM & - & 0.8 & 0.3 & 1.8 & 1.4 & 1.4 \\
\hline Breed effect ( $P$-value $)$ & - & 0.13 & 0.002 & 0.02 & 0.002 & 0.0005 \\
\hline \multicolumn{7}{|l|}{ Contrast ( $P$-value $)$} \\
\hline Ho vs. crossbreds $\left(\mathrm{F}_{1}+\mathrm{F}_{2}+\mathrm{F}_{3}\right)$ & - & 0.17 & 0.009 & 0.10 & 0.01 & 0.004 \\
\hline (Ho vs. crossbreds) $\times$ herd & - & $<0.0001$ & 0.03 & 0.07 & 0.02 & 0.02 \\
\hline
\end{tabular}

min. The average asymptotic potential curd firmness theoretically achievable at infinite time in absence of curd syneresis was close to $58 \mathrm{~mm}$, and the average $\mathrm{k}_{\mathrm{CF}}$ and $\mathrm{k}_{\mathrm{SR}}$ were 9.22 and $1.13 \% / \mathrm{min}$, respectively. On average, the $\mathrm{CF}_{\max }$ was $38.6 \mathrm{~mm}$, and was achieved 47 min after rennet addition (time to $\mathrm{CF}_{\max }$ ).

There were differences between the herds with respect to most of the curd firming $\left(\mathbf{C F}_{\mathbf{t}}\right)$ equation parameters, suggesting large differences in the coagula- tion times and curd firming patterns of milk from the 2 herds (Figure 2). The $\mathrm{CF}_{\mathrm{t}}$ parameters were also affected by breed, as milk from the crossbred cows had greater potential and maximum curd firmness and a slower syneresis rate than milk from the purebred Ho cows. Although the comparisons between purebred Ho and crossbred cows with respect to the $\mathrm{CF}_{\mathrm{t}}$ equation parameters mostly differed between the 2 herds $(P<$ $0.01)$, the magnitude of these differences was smaller

Table 4. Comparison between purebred Holsteins and 3 generations of 3-breed rotational (VR-Mo-Ho) crossbred cows from herds A and B (data set 1): LSM and SEM for curd firming $\left(\mathrm{CF}_{\mathrm{t}}\right)$ equation parameters

\begin{tabular}{|c|c|c|c|c|c|c|c|}
\hline Item & Cows, no. & \multicolumn{6}{|c|}{$\mathrm{CF}_{\mathrm{t}}$ equation parameter ${ }^{1}$} \\
\hline \multicolumn{8}{|l|}{ Herd } \\
\hline $\mathrm{B}$ & 508 & $20.4^{\mathrm{b}}$ & 9.7 & $1.2^{\mathrm{a}}$ & $66.6^{\mathrm{a}}$ & $45.3^{\mathrm{a}}$ & $44.8^{\mathrm{b}}$ \\
\hline SEM & - & 0.7 & 0.5 & 0.1 & 2.1 & 1.3 & 1.0 \\
\hline \multicolumn{8}{|l|}{ Breed combination $^{2}$} \\
\hline $\mathrm{Mo} \times(\mathrm{VR} \times \mathrm{Ho})\left(\mathrm{F}_{2}\right)$ & 95 & 26.6 & 9.3 & 0.9 & 51.6 & 36.1 & 49.4 \\
\hline $\mathrm{Ho} \times[\mathrm{Mo} \times(\mathrm{VR} \times \mathrm{Ho})]\left(\mathrm{F}_{3}\right)$ & 184 & 25.1 & 9.7 & 1.0 & 56.4 & 39.5 & 48.2 \\
\hline SEM & - & 0.8 & 0.4 & 0.1 & 1.9 & 1.2 & 1.0 \\
\hline Breed effect ( $P$-value) & - & 0.21 & 0.26 & 0.15 & 0.003 & 0.002 & 0.38 \\
\hline \multicolumn{8}{|l|}{ Contrast ( $P$-value) } \\
\hline Ho vs. crossbreds $\left(F_{1}+F_{2}+F_{3}\right)$ & - & 0.28 & 0.28 & 0.04 & 0.04 & 0.04 & 0.13 \\
\hline (Ho vs. crossbreds) $\times$ herd & - & $<0.0001$ & 0.47 & $<0.0001$ & $<0.0001$ & 0.0002 & $<0.0001$ \\
\hline
\end{tabular}

\footnotetext{
${ }^{a, b}$ Least squares means across columns with different superscripts are significantly different $(P<0.05)$.

${ }^{1} \mathrm{RCT}_{\mathrm{eq}}=$ rennet coagulation time estimated according to curd firming change over time modeling $\left(\mathrm{CF}_{\mathrm{t}}\right)$; $\mathrm{k}_{\mathrm{CF}}=$ curd firming instant rate constant; $\mathrm{k}_{\mathrm{SR}}=$ syneresis instant rate constant; $\mathrm{CF}_{\mathrm{P}}=$ asymptotic potential curd firmness; $\mathrm{CF}_{\max }=$ maximum curd firmness; $\mathrm{t}_{\max }=$ time to reach $\mathrm{CF}_{\max }$.

${ }^{2} \mathrm{Ho}=$ Holstein; $\mathrm{VR}=$ Viking Red; $\mathrm{Mo}=$ Montbéliarde. $\mathrm{F}_{1}, \mathrm{~F}_{2}, \mathrm{~F}_{3}$, and $\mathrm{F}_{4}=$ first, second, third, and fourth generation, respectively.
} 


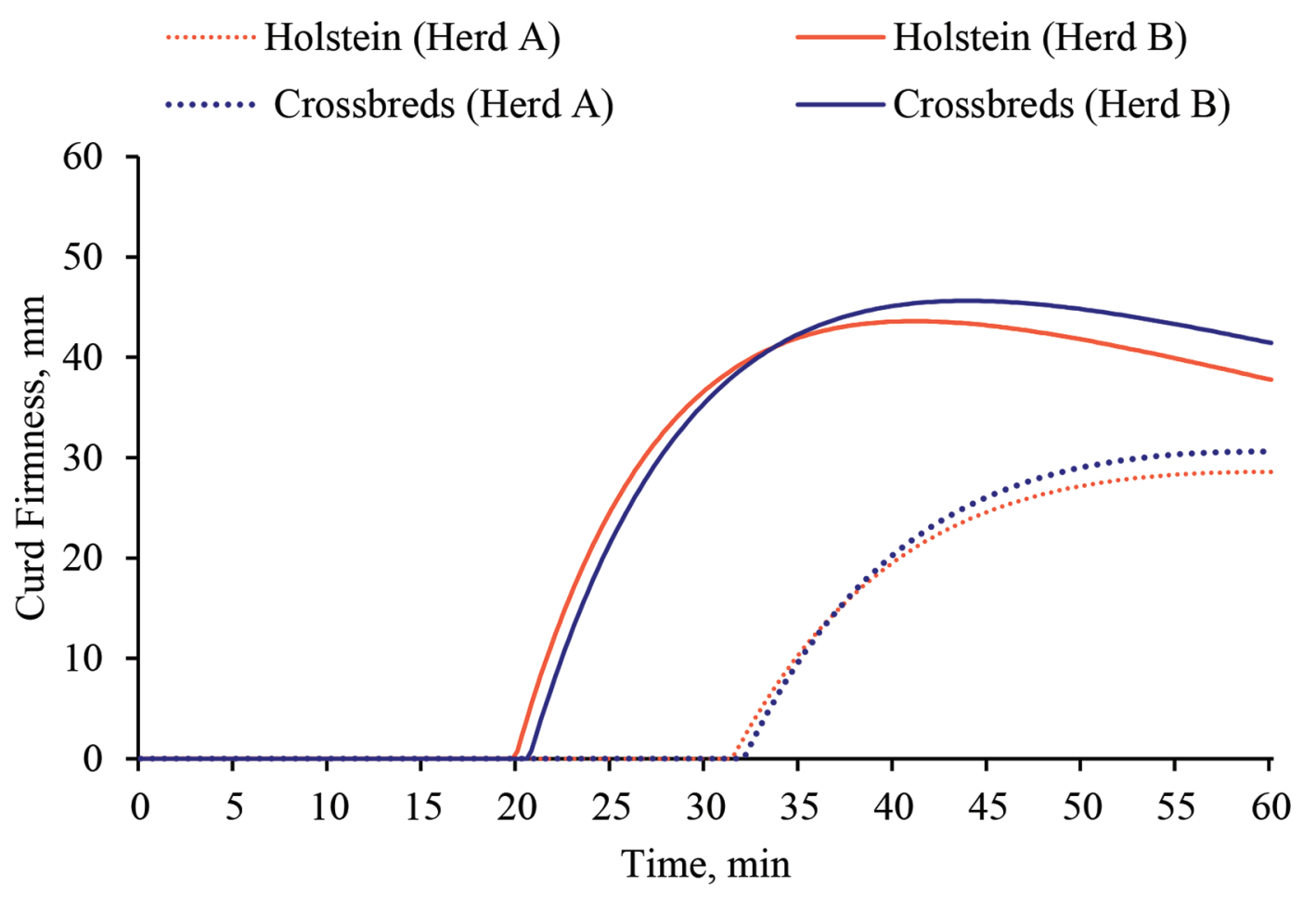

Figure 2. Pattern of curd firming after rennet addition $\left(\mathrm{CF}_{\mathrm{t}}\right.$ equation) of milk samples from Holstein and 3-breed rotational crossbred cows (average of first-, second-, and third-generation breed combinations) kept in herds A and B (data set 1).

than that between the 2 herds. Indeed, as Figure 2 shows, the milk produced by herd $\mathrm{B}$ was much more suited to cheese production than the milk from herd A. In both herds, the milk from the crossbred cows was similar to the milk from the Ho cows with regard to coagulation and the first part of the curd firming process $\left(\mathrm{RCT}_{\mathrm{eq}}\right.$ and $\mathrm{k}_{\mathrm{CF}}$ were not significantly different) but was clearly superior thereafter, with greater asymptotic potential curd firmness and $\mathrm{CF}_{\max }$ and a much smaller decrease due to syneresis $\left(\mathrm{k}_{\mathrm{SR}}\right)$. This general trend was slightly different in the 2 herds, as the superiority of the milk from crossbred cows was more evident in herd B than in herd A (Figure 2).

$C Y$ and Milk Nutrient Recovery in the Curd. The LSM for CY and milk nutrient recovery in the curd across herds and breeds are given in Table 5. On average, the milk yielded $170 \mathrm{~g}$ of fresh curd/ $\mathrm{kg}$ (48 g of solids, $122 \mathrm{~g}$ of retained water), with a recovery in the curd of almost $80 \%$ of the milk protein and $57 \%$ of the fat contents. Curd CY was significantly affected by herd effect $(P<0.05)$, but the differences in $\mathrm{CY}$ between the herds seemed entirely due to the different water contents entrapped in the curd, as solid CY was almost identical in the 2 herds. Milk protein recovered in the curd was also similar in the 2 herds, but we found differences in $\mathrm{REC}_{\mathrm{fat}}$. Both purebred Ho and crossbred cows yielded milk with very similar CY coefficients and REC traits. However, comparison of purebred Ho and crossbred cows in terms of $\mathrm{CY}$ revealed significant differences between the 2 herds $(P=0.04)$. In herd A the CY of crossbred cows was almost $1.5 \%$ greater than that of purebred Ho, whereas in herd B the CY of purebred Ho and crossbred cows were almost identical (Figure 1).

\section{Comparison Among Crossbred Cows (Data Set 2)}

Milk Yield and Composition. Milk yield and composition traits for the different crossbreed combinations are given in Table 6. On average, crossbred cows produced almost $30 \mathrm{~kg}$ of milk/d, with fat and protein contents close to 3.80 and $3.75 \%$, respectively. The sire-breed sequence did not affect milk yield and composition except for average milk protein and lactose contents. Indeed, starting the crossbreeding program with VR sires rather than Mo sires slightly improved the average milk protein contents (3.77 vs. $3.70 \%)$ and slightly reduced average milk lactose contents (5.00 vs. $5.05 \%$ ). The performances of cows from different crossbred generations were similar in terms of milk yield and composition, with few exceptions $\left(\mathrm{F}_{1}\right.$ vs. other generations for casein content; $\mathrm{F}_{3}$ vs. $\mathrm{F}_{4}$ for fat content). Like- 
Table 5. Comparison between purebred Holsteins and 3 generations of 3-breed rotational (VR-Mo-Ho) crossbred cows from herds A and B (data set 1): LSM and SEM for cheese yield (CY) and milk nutrient recovery in curd (REC)

\begin{tabular}{|c|c|c|c|c|c|c|}
\hline \multirow[b]{2}{*}{ Item } & \multirow[b]{2}{*}{ Cows, no. } & \multicolumn{3}{|c|}{$\mathrm{CY},{ }^{1} \%$} & \multicolumn{2}{|c|}{$\mathrm{REC}^{2} \%$} \\
\hline & & Curd & Solids & Water & Protein & Fat \\
\hline \multicolumn{7}{|l|}{ Herd } \\
\hline A & 320 & $17.56^{\mathrm{a}}$ & 4.86 & $12.70^{\mathrm{a}}$ & 79.84 & $58.43^{\mathrm{a}}$ \\
\hline $\mathrm{B}$ & 510 & $16.68^{\mathrm{b}}$ & 4.83 & $11.83^{\mathrm{b}}$ & 80.18 & $56.52^{\mathrm{b}}$ \\
\hline SEM & - & 0.21 & 0.07 & 0.16 & 0.17 & 1.00 \\
\hline \multicolumn{7}{|l|}{ Breed combination $^{3}$} \\
\hline Purebred Ho & 468 & 17.02 & 4.80 & 12.22 & 79.92 & 57.37 \\
\hline $\mathrm{VR} \times \operatorname{Ho}\left(\mathrm{F}_{1}\right)$ & 82 & 17.30 & 4.99 & 12.33 & 80.02 & 57.25 \\
\hline $\mathrm{Mo} \times(\mathrm{VR} \times \mathrm{Ho})\left(\mathrm{F}_{2}\right)$ & 95 & 16.83 & 4.67 & 12.12 & 80.01 & 57.11 \\
\hline $\mathrm{Ho} \times[\mathrm{Mo} \times(\mathrm{VR} \times \mathrm{Ho})]\left(\mathrm{F}_{3}\right)$ & 185 & 17.33 & 4.91 & 12.39 & 80.08 & 58.17 \\
\hline SEM & - & 0.23 & 0.08 & 0.19 & 0.22 & 1.23 \\
\hline Breed effect ( $P$-value) & - & 0.30 & 0.02 & 0.73 & 0.91 & 0.91 \\
\hline \multicolumn{7}{|l|}{ Contrast ( $P$-value $)$} \\
\hline Ho vs. crossbreds $\left(F_{1}+F_{2}+F_{3}\right)$ & - & 0.44 & 0.28 & 0.72 & 0.53 & 0.89 \\
\hline (Ho vs. crossbreds $) \times$ herd & - & 0.04 & 0.29 & 0.05 & 0.10 & 0.07 \\
\hline
\end{tabular}

${ }^{\mathrm{a}, \mathrm{b}}$ Least squares means across columns with different superscripts are significantly different $(P<0.05)$.

${ }^{1}$ Curd $=$ fresh cheese yield; Solids $=$ total solids cheese yield; Water $=$ water trapped in the curd.

${ }^{2}$ Protein $=$ milk protein retained in the curd; $\mathrm{REC}_{\mathrm{fat}}=$ milk fat retained in the curd .

${ }^{3} \mathrm{Ho}=$ Holstein; $\mathrm{VR}=$ Viking Red; Mo $=$ Montbéliarde. $\mathrm{F}_{1}, \mathrm{~F}_{2}, \mathrm{~F}_{3}$, and $\mathrm{F}_{4}=$ first, second, third, and fourth generation, respectively.

wise, the performances of crosses from the 2 rotational sequences and of the same generation were generally similar, the only difference being the protein content of milk from $\mathrm{F}_{4}$ crossbred cows.

Single-Point MCP, Curd Firming Pattern, and $C Y$. The LSM for single-point MCP and CY across the different crossbreed combinations are shown in Table 7 , and those for $\mathrm{CF}_{\mathrm{t}}$ equation parameters can be found in Supplemental Table S2 (https://doi.org/ 10.3168/jds.2019-17576). Whether the crossbreeding program began with VR or Mo sires did not affect the coagulation properties and the CY of milk (Table 7).

Table 6. Comparison between 4 generations of crossbred cows from 2 rotational sequences (VR-Mo-Ho and Mo-VR-Ho; data set 2, herd B): LSM and SEM for milk yield (MY), milk nutrient contents, and SCS

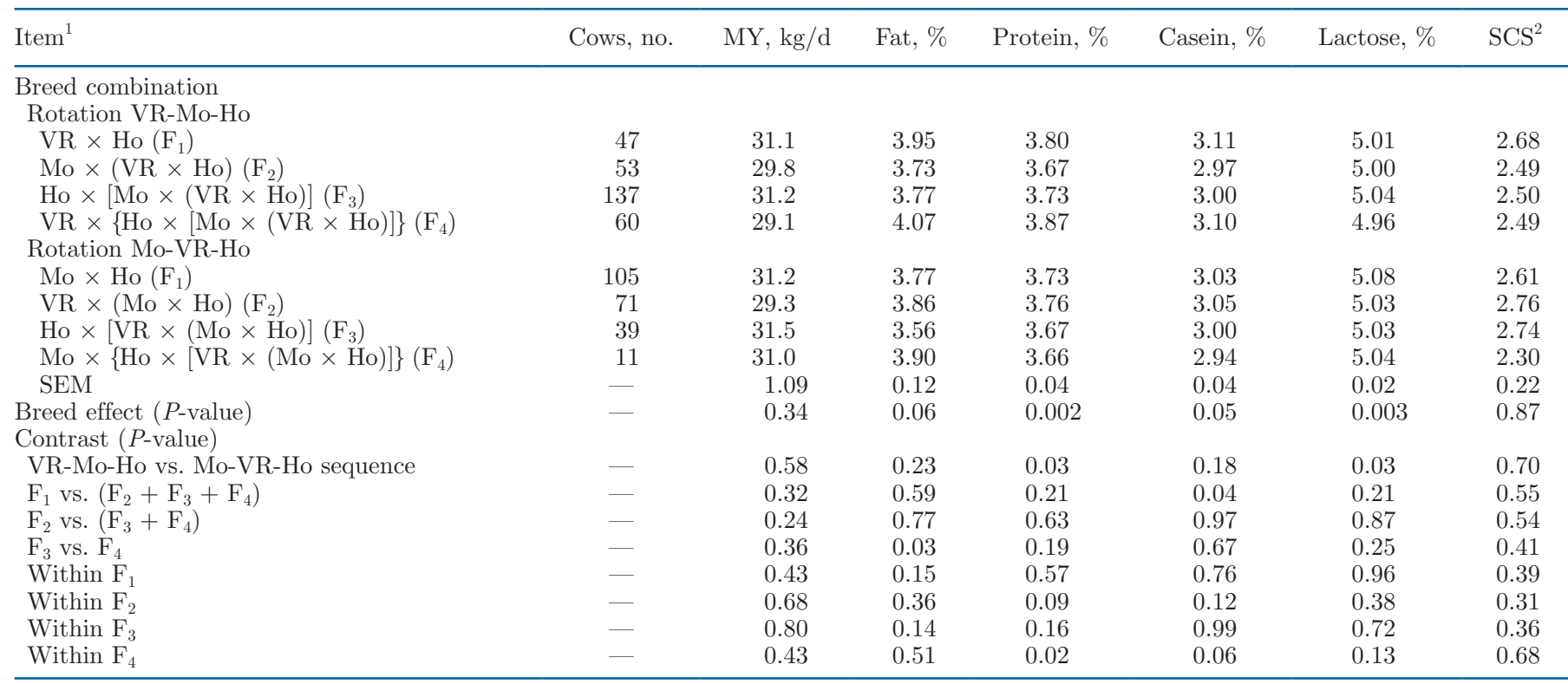

${ }^{1} \mathrm{Ho}=$ Holstein; $\mathrm{VR}=$ Viking Red; Mo $=$ Montbéliarde. $\mathrm{F}_{1}, \mathrm{~F}_{2}, \mathrm{~F}_{3}$, and $\mathrm{F}_{4}=$ first, second, third, and fourth generation, respectively. ${ }^{2} \mathrm{SCS}=3+\log _{2}(\mathrm{SCC} / 100,000)$. 
Table 7. Comparison between 4 generations of crossbred cows from 2 rotational sequences (VR-Mo-Ho and Mo-VR-Ho; data set 2, herd B): LSM and SEM for single-point milk coagulation properties and fresh cheese yield (CY)

\begin{tabular}{|c|c|c|c|c|c|c|c|}
\hline \multirow[b]{2}{*}{ Item $^{1}$} & \multirow[b]{2}{*}{ Cows, no. } & \multicolumn{5}{|c|}{ Milk coagulation property $^{2}$} & \multirow[b]{2}{*}{$\mathrm{CY}, \%$} \\
\hline & & $\mathrm{RCT}, \min$ & $\mathrm{k}_{20}, \min$ & $\mathrm{a}_{30}, \mathrm{~mm}$ & $\mathrm{a}_{45}, \mathrm{~mm}$ & $\mathrm{a}_{60}, \mathrm{~mm}$ & \\
\hline \multicolumn{8}{|l|}{ Rotation VR-Mo-Ho } \\
\hline $\mathrm{VR} \times \mathrm{Ho}\left(\mathrm{F}_{1}\right)$ & 47 & 19.5 & 4.1 & 40.1 & 44.2 & 42.0 & 17.06 \\
\hline $\mathrm{Mo} \times(\mathrm{VR} \times \mathrm{Ho})\left(\mathrm{F}_{2}\right)$ & 53 & 21.3 & 5.3 & 32.9 & 40.9 & 39.2 & 16.27 \\
\hline $\mathrm{Ho} \times[\mathrm{Mo} \times(\mathrm{VR} \times \mathrm{Ho})]\left(\mathrm{F}_{3}\right)$ & 137 & 20.4 & 4.8 & 34.9 & 42.4 & 40.5 & 16.88 \\
\hline Mo $\times$ Ho $\left(\mathrm{F}_{1}\right)$ & 105 & 19.1 & 4.6 & 36.1 & 42.6 & 40.6 & 17.32 \\
\hline $\mathrm{VR} \times(\mathrm{Mo} \times \mathrm{Ho})\left(\mathrm{F}_{2}\right)$ & 71 & 21.6 & 5.2 & 29.9 & 40.6 & 38.6 & 17.21 \\
\hline $\mathrm{Ho} \times[\mathrm{VR} \times(\mathrm{Mo} \times \mathrm{Ho})]\left(\mathrm{F}_{3}\right)$ & 39 & 21.7 & 5.6 & 34.8 & 39.7 & 37.5 & 16.51 \\
\hline $\mathrm{Mo} \times\{\mathrm{Ho} \times[\mathrm{VR} \times(\mathrm{Mo} \times \mathrm{Ho})]\}\left(\mathrm{F}_{4}\right)$ & 11 & 18.6 & 4.8 & 33.7 & 37.5 & 35.5 & 16.18 \\
\hline SEM & - & 1.2 & 0.4 & 2.7 & 2.1 & 2.1 & 0.37 \\
\hline Breed effect ( $P$-value) & - & 0.0005 & 0.008 & 0.001 & 0.006 & 0.01 & 0.05 \\
\hline \multicolumn{8}{|l|}{ Contrast ( $P$-value) } \\
\hline Within $\mathrm{F}_{2}$ & - & 0.83 & 0.96 & 0.33 & 0.88 & 0.74 & 0.03 \\
\hline Within $\mathrm{F}_{3}$ & - & 0.34 & 0.13 & 0.96 & 0.14 & 0.09 & 0.37 \\
\hline Within $\mathrm{F}_{4}$ & - & 0.01 & 0.17 & 0.17 & 0.72 & 0.81 & 0.07 \\
\hline
\end{tabular}

${ }^{1} \mathrm{Ho}=$ Holstein; $\mathrm{VR}=$ Viking Red; Mo = Montbéliarde. $\mathrm{F}_{1}, \mathrm{~F}_{2}, \mathrm{~F}_{3}$, and $\mathrm{F}_{4}=$ first, second, third, and fourth generation, respectively.

${ }^{2} \mathrm{RCT}=$ measured rennet gelation time; $\mathrm{k}_{20}=$ time interval between gelation and attainment of curd firmness of $20 \mathrm{~mm} ; \mathrm{a}_{30}\left(\mathrm{a}_{45}, \mathrm{a}_{60}\right)=$ curd firmness after $30(45,60)$ min from rennet addition.

However, compared with crossbred cows of the other generations, the milk from $\mathrm{F}_{1}$ crossbreds had better single-point RCT, reached a curd firmness of $20 \mathrm{~mm}$ more quickly, and had a stronger curd firmness at 30, 45 , and $60 \mathrm{~min}$ from rennet addition $(P<0.05)$. The superior single-point MCP traits of $\mathrm{F}_{1}$ crossbred cows were due to their more favorable pattern of curd firming after rennet addition compared with crossbred cows of the other generations. Aside from $\mathrm{F}_{1}$, the cows from the other crossbred generations had comparable singlepoint MCP traits. Likewise, the MCP traits of crosses of the same generation from the 2 rotational sequences were generally similar, with the exceptions of curd firmness in $\mathrm{F}_{1}$ cows and $\mathrm{RCT}$ in $\mathrm{F}_{4}$ cows.

\section{DISCUSSION}

In the last decade, several studies have investigated the effects of crossbreeding in dairy cattle and have looked at different breeds and different crossbreeding sequences. The present study focused on a 3-breed rotation system in which purebred Ho heifers and cows were inseminated with semen from VR bulls, and subsequently Mo semen was used on their daughters. The latter 2 breeds are known for having a lower milk volume but higher milk fat and protein percentages than the Ho breed and have been more intensively selected for the improvement of functional traits (Dezetter et al., 2015). Although other studies have investigated the effects of the same crossbreeding system on certain milk and animal traits (see, e.g., Malchiodi et al., 2014a,b; Hazel et al., 2017a,b; Shonka-Martin et al., 2019a,b), to the best of our knowledge this is the first study to focus on the cheese-making ability of milk from crossbred cows from a long-term rotational crossbreeding system up to the fourth generation.

\section{Comparison Between Purebred Ho and Crossbred Cows}

The 2 herds involved in our study are representative of the 2 most important dairy production systems in northern Italy, where the milk is largely destined for the production of long-ripened, hard PDO cheeses; namely, Grana Padano (herd A) and Parmigiano-Reggiano (herd B). The huge differences in the yield, quality, and technological properties of milk from the 2 herds are mainly due to differences in feeding and management conditions and reflect the different production regulations laid down by the 2 PDO consortia. Grana Padano is generally produced on large farms using many silages (especially corn silage and ear silage) and concentrates, whereas the use of silage is prohibited by the regulations governing Parmigiano-Reggiano production, and 
the diets are instead based on dry forages (alfalfa and meadow hays) and concentrates.

The slightly lower volume of milk yielded by crossbred cows compared with Ho cows that we found in this study is consistent with the results of several other studies dealing with 2- and 3-breed crosses from the Ho, Mo, and VR breeds (Heins and Hansen, 2012; Malchiodi et al., 2014b; Hazel et al., 2017b; Shonka-Martin et al., 2019a). The magnitude of the difference found in the present study $(-5.5 \%$ with respect to the milk yield of purebred Ho) is intermediate between the $-2 \%$ reported by Hazel et al. (2017b) for Mo $\times$ Ho and VR $\times$ Ho first-generation cows and the $-9 \%$ reported by Malchiodi et al. (2014b) for 2 generations of 3-breed crosses of Ho, Mo, and VR and is almost identical to that reported in another multigeneration experiment using the same rotational system by Shonka-Martin et al. (2019a).

The milk produced by crossbred cows was richer in protein and casein compared with the milk from purebred Ho cows, confirming results reported by Heins and Hansen (2012), Ezra et al. (2016), and Hazel et al. (2017b), who looked at 2-breed crosses using Mo or Nordic Red sires on Ho cows, and by Malchiodi et al. (2014b) and Shonka-Martin et al. (2019a), who examined 3-breed crosses of the Ho, Mo, and VR breeds.

The lower SCS of crossbred cows compared with purebred Ho observed in this study is in agreement with the findings of Heins and Hansen (2012), who compared first-generation Mo $\times$ Ho and Scandinavian Red $\times$ Ho with purebred Ho, and of Dezetter et al. (2015), who reported lower SCS across lactation in Mo $\times$ Ho cows than in purebred Ho. However, Hazel et al. $(2017 b)$ reported that $\mathrm{Mo} \times \mathrm{Ho}$ and $\mathrm{VR} \times$ Ho cows did not differ from Ho cows with regard to SCS during their first lactation, as did Malchiodi et al. (2014b) in a study of 3-breed crosses of the Ho, Mo, and VR breeds. Interestingly, we found that the reduction in SCS associated with crossbred cows was particularly evident in the most productive herd, where cows were possibly under more stressful conditions and a greater metabolic load. The response of crossbred cows and the magnitude of heterosis are known to be affected by the production environment and the level of herd production (Bryant et al., 2007; Penasa et al., 2010; Kargo et al., 2012). Concerning udder health, in a study comparing Nordic Red $\times$ Ho cows with purebred Ho cows, Clasen et al. (2019) reported a lower incidence of mastitis in crossbred cows, particularly when they were raised in herds with a high production level, whereas there were only small or nonsignificant differences between crossbred and purebred cows when they were raised in herds with average or low production levels.
The average MCP traits observed in the present study were slightly worse than those reported by Malchiodi et al. (2014b) for Ho and crossbred cows; the milk samples in that study had a 3-min shorter RCT, required almost 1 min less to reach a curd firmness of $20 \mathrm{~mm}\left(\mathrm{k}_{20}\right)$, and had a 3.5-mm greater curd firmness at $30 \mathrm{~min}$ from rennet addition due to a better $\mathrm{k}_{\mathrm{CF}}$. The laboratory, instruments, and procedures were the same in the 2 studies but the herds differed, and there were partial differences in the genetic combinations of the crossbred cows and in the milk sample storage conditions [refrigerated in the Malchiodi et al. (2014b) study; frozen in ours].

The positive effects of crossbred cows compared with Ho cows on curd firming parameters are comparable with results of Malchiodi et al. (2014b) even though the sires used in that study included Brown Swiss in addition to the Swedish Red and Mo breeds. Differences in MCP between purebred Ho and crossbred cows may be attributable to the effects of different breeds and the possible contribution of heterosis. Breed can strongly affect MCP traits (Bittante et al., 2012). Compared with Ho, the Nordic red breeds included in the VR breeding program, such as the Swedish Red, have been linked with a high rate of noncoagulation and slow curd firming (Poulsen et al., 2017; Nilsson et al., 2019). However, in this study the incidence of noncoagulating samples was not increased in the $\mathrm{F}_{1} \mathrm{VR} \times$ Ho cows, which also exhibited curd firming traits comparable with those of the other genetic groups. Moreover, some studies have found milk from Mo cows to have better coagulation properties than milk from Ho cows (Macheboeuf et al., 1993; Bittante et al., 2012). Among-breed differences in MCP may be partially explained by differences in genetic variants of milk protein content (Bittante et al., 2012). In this regard, milk from crossbred cows sired by Swedish Red and Mo bulls has been found to have higher $\mathrm{\kappa}-\mathrm{CN}$ contents and proportions than milk from Ho cows (Maurmayr et al., 2018), which is consistent with the favorable curd firmness properties of the milk from crossbreds in the present study. Finally, it is well known that heterosis can be important and positive for yield traits but may have negligible effects on nutrient contents (Dezetter et al., 2015). There is currently no literature on the effects of heterosis for MCP traits, and the data from the present study are not suitable for estimating heterosis because we did not include pure VR and Mo cows for comparison.

Interestingly, the favorable effects of crossbred cows compared with Ho cows on curd firming parameters were particularly evident in the herd with the greatest milk yield, but also the worst MCP traits. In large surveys of commercial dairy farms, dairy system was found 
to affect MCP (Bittante et al., 2015); moreover, an increase in herd productivity has been related to delayed coagulation time but not reduced curd firmness (Stocco et al., 2017). Clasen et al. (2019) reported that the response of $\mathrm{F}_{1}$ Nordic Red $\times$ Ho cows compared with purebred Ho cows was independent of the production level of the herds, but they examined yield and some functional traits rather than the coagulation properties of the milk.

The efficiency of the cheese-making process depends on CY as well as the recovery of milk nutrient constituents in the curd and their loss in the whey (Banks, 2007). Given the increasing use of milk for cheese production in many countries, factors affecting the CY of milk are of relevance to the profitability of the dairy sector. In the present study, we found the average CY of curd to be generally greater than that reported in other studies using laboratory procedures for individual cheese manufacturing (Cipolat-Gotet et al., 2016; Stocco et al., 2018), mainly due to greater water retention in the curd. Regarding the proportion of milk nutrients retained in the curd, the average $\mathrm{REC}_{\text {protein }}$ obtained in this study is fully consistent with that reported by the above-mentioned authors, whereas the average $\mathrm{REC}_{\text {fat }}$ is much lower. Variations in these parameters have been associated with both animal-related factors, such as breed, parity, stage of lactation, feeding, and management, and cheese-making conditions, such as milk storage before processing and the cheese-making procedures (Cipolat-Gotet et al., 2016). With regard to storage, the milk samples in the present study were frozen before being processed into cheese, whereas in other studies the milk was refrigerated before processing. By freezing the samples, we were able to sample a larger number of cows in the same sampling session and, consequently, to remove the effect of the day and season of sampling, even though it resulted in a greater loss of fat in the whey. These conditions may therefore affect the comparison between our absolute $\mathrm{CY}$ and $\mathrm{REC}_{\mathrm{fat}}$ values and those of other trials but not the comparison among different breed combinations within this study, as the milk storage conditions and processing were the same for all the samples.

Breed has been shown to greatly affect CY traits, and differences among several dairy and dual-purpose breeds have been reported (Stocco et al., 2018). In previous large surveys (Cecchinato et al., 2015; Stocco et al., 2018), we found that the technological aptitude of milk from the Italian Simmental, a breed with many genetic exchanges with the French Mo, was better than that of Ho cows. Similarly, Martin et al. (2009) reported that milk from Mo had a greater CY than milk from Ho cows, although others found no differences between the 2 breeds (Verdier-Metz et al., 1998). Unfortunately, no information is available regarding comparisons of different breed combinations or the role of heterosis in CY traits.

The farms differed for $\mathrm{CY}_{\text {curd }}$, mainly due to differences in the amount of water retained in the curd. Stocco et al. (2018) reported that herd was an important source of variation in $\mathrm{CY}_{\text {curd }}$ and that differences among herds were larger for water than for solid retention in curd. The interaction between the effects of herd and of crossbreeding was significant for $\mathrm{CY}_{\text {curd }}$, but it was only a tendency for REC traits (Table 5). Again, the crossbred cows were superior to the Ho cows in the herd with the highest production level but not in the other.

\section{Comparison Among Crossbred Cows}

For the long-term management of crossbreeding as a systematic mating procedure on dairy farms, a 3-breed rotational crossbreeding program has been recommended as an optimal strategy for dairy herds (Sørensen et al., 2008). Indeed, compared with the use of only 2 breeds, using 3 breeds in rotational crossing systems results in a greater level of heterosis (Sørensen et al., 2008; Hazel et al., 2014). Most studies in the literature dealing with crossbreeding in dairy cows have compared the performances of purebred (usually Ho) and first-generation crossbred cows, but few have assessed the performance of the second or subsequent generations within a rotational crossbreeding system and compared the outcomes of crossbred cows of different crossbreeding generations. Recently, Shonka-Martin et al. (2019a) compared cows obtained from a 3-breed rotational crossbreeding system involving Mo, VR, and Ho breeds and purebred Ho, but the study was concerned with comparing the purebreds and crossbreds, and the results regarding cows from the different crossbred generations were not reported. In a comparison of purebred $F_{1}$ crossbred and backcross cows from Ho, Mo, and Normande breeds, Dezetter et al. (2015) found recombination estimates that were consistently negative but characterized by large standard errors, so they never differed significantly from zero.

In this study, crossbred cows of different generations were similar in terms of the yield, composition, and cheese-making properties of milk, with only some sporadic differences despite large differences in their breed composition, as the genes from the Ho breed accounted for $50,25,62.5$, and $31.25 \%$ of the entire genome of cows of the $\mathrm{F}_{1}, \mathrm{~F}_{2}, \mathrm{~F}_{3}$, and $\mathrm{F}_{4}$ generations, respectively. Heterosis was correspondingly $100,100,75$, and $87.5 \%$ of the maximum level. The only exception regarded the overall better MCP of $\mathrm{F}_{1}$ cows compared with crossbreds 
of the following generations $\left(\mathrm{F}_{2}+\mathrm{F}_{3}+\mathrm{F}_{4}\right)$. Comparisons of crosses from the 2 rotational sequences within each generation also showed them performing very similarly, with the main exception being the slightly better curd firmness traits in the milk from VR $\times$ Ho cows than in that from Mo $\times$ Ho $F_{1}$ cows. Malchiodi et al. (2014b) also found no differences in milk yield and composition or SCS between $\mathrm{F}_{1}$ and $\mathrm{F}_{2}$ crossbred cows from Swedish Red, Mo, and Brown Swiss sires and between different crosses within each generation. Moreover, Malchiodi et al. (2014b) reported some differences in MCP traits between different crosses within both the first and second crossbred generations but not between the first and second generations. However, that study looked only at 2 generations of crossbred cows, and it included Brown Swiss as a sire breed but not backcrosses to $\mathrm{Ho}_{(}\left(\mathrm{F}_{3}\right)$ in the genetic lines examined.

Last, the slight, sporadic differences found between the 2 rotational crossbreeding sequences within each crossbred generation explain why the sire-breed sequence used in the 3-breed rotational program did not affect its overall outcome. Therefore, crossbred cows produced more or less the same volume of milk and cheese regardless of whether the mating program started with the VR or Mo sire breed or of the generation reared. This may be a useful practical indication for farmers adopting this crossbreeding program.

\section{CONCLUSIONS}

Crossbreeding is of interest to commercial dairy farmers to improve the robustness of their dairy cows, thereby enhancing their health status, fertility, and longevity. A 3-breed rotational crossbreeding program has been proposed as an effective strategy for systematic crossbreeding in dairy farms. This study adds new knowledge about the long-term effects of such a program on traits that have received less attention in the literature, such as the technological properties and cheese-making ability of milk, and has taken into account the performance of crossbred cows up to the fourth generation of the rotational crossbreeding system. Data from this study confirm that crossbred cows yield a lower volume of milk compared with purebred Ho, but the milk protein and casein contents were higher and the SCS was lower. Milk from crossbred cows also had slightly better milk coagulation and curd firming properties than the milk of purebred Ho, but there were no significant differences in $\mathrm{CY}$ and milk nutrient recovery in the curd. The 3-breed rotational breeding system using Mo, VR, and Ho sires can therefore also be implemented in farming systems specializing in cheese production. The favorable response of crossbred cows compared with purebred Ho cows with respect to SCS, curd firming properties, and CY was greater and more evident in the herd with the highest production level and using many silages in the diet, where cows may experience a greater metabolic load. However, speculation that there may be interactions with production systems in the response of crossbred cows needs further investigation. Crossbred cows of different generations and breed rotation sequences performed similarly, with the exception of the better curd firming properties of milk from $\mathrm{F}_{1}$ crossbred cows. Reciprocal crosses within each crossbred generation were also fairly similar in milk quality and technological and CY traits. Therefore, whether the VR or the Mo sire breed was used to produce $\mathrm{F}_{1}$ cows at the start of the rotational crossbreeding program had no practical implications for the overall performance of the program, and there were no appreciable changes in the yield, composition, and cheese-making ability of milk and the proportions of milk nutrients retained in the cheese in the subsequent crossbreeding generations.

\section{ACKNOWLEDGMENTS}

Funding for this project was provided by University of Padova (BIRD 188213/18), Genesi Project S.r.l. (Castelnovo Sotto, Reggio Emilia, Italy), and ProCROSS Aps (Randers, Denmark). The authors thank the technical staff of the Department of Agronomy, Food, Natural Resources, Animals and Environment (University of Padova, Italy) for their assistance in data collection. Gratitude is expressed to the owners and managers of the herds for their cooperation and support [special thanks to Martino Bondioli, allevamento Bondioli, Carpenedolo (BS), Italy, Gian Luca Cavani, and Carmelo Monteleone, Albalat, Cortile di Carpi (MO), Italy]. The authors declare no conflicts of interest.

\section{REFERENCES}

Ali, A. K. A., and G. E. Shook. 1980. An optimum transformation for somatic cell concentration in milk. J. Dairy Sci. 63:487-490. https: //doi.org/10.3168/jds.S0022-0302(80)82959-6.

Banks, J. M. 2007. Cheese yield. Pages 100-114 in Cheese Problems Solved. P. L. H. McSweeney, ed. Woodhead Publishing, Cambridge, UK.

Berry, D. P. 2018. Symposium review: Breeding a better cow-Will she be adaptable? J. Dairy Sci. 101:3665-3685. https://doi.org/10 .3168/jds.2017-13309.

Bittante, G., C. Cipolat-Gotet, F. Malchiodi, E. Sturaro, F. Tagliapietra, S. Schiavon, and A. Cecchinato. 2015. Effect of dairy farming system, herd, season, parity, and days in milk on modeling of the coagulation, curd firming, and syneresis of bovine milk. J. Dairy Sci. 98:2759-2774. https://doi.org/10.3168/jds.2014-8909.

Bittante, G., B. Contiero, and A. Cecchinato. 2013. Prolonged observation and modelling of milk coagulation, curd firming, and syneresis. Int. Dairy J. 29:115-123. https://doi.org/10.1016/j.idairyj .2012.10.007. 
Bittante, G., M. Penasa, and A. Cecchinato. 2012. Invited review: Genetics and modeling of milk coagulation properties. J. Dairy Sci. 95:6843-6870. https://doi.org/10.3168/jds.2012-5507.

Blöttner, S., B. J. Heins, M. Wensch-Dorendorf, L. B. Hansen, and H. H. Swalve. 2011. Brown Swiss $\times$ Holstein crossbreds compared with pure Holsteins for calving traits, body weight, backfat thickness, fertility, and body measurements. J. Dairy Sci. 94:1058-1068. https://doi.org/10.3168/jds.2010-3305.

Bryant, J. R., N. López-Villalobos, J. E. Pryce, C. W. Holmes, D. L. Johnson, and D. J. Garrick. 2007. Short communication: Effect of environment on the expression of breed and heterosis effects for production traits. J. Dairy Sci. 90:1548-1553. https://doi.org/10 .3168/jds.S0022-0302(07)71640-5.

Buckley, F., N. López-Villalobos, and B. J. Heins. 2014. Crossbreeding: Implications for dairy cow fertility and survival. Animal 8(Suppl. 1):122-133. https://doi.org/10.1017/S1751731114000901.

Cecchinato, A., A. Albera, C. Cipolat-Gotet, A. Ferragina, and G. Bittante. 2015. Genetic parameters of cheese yield and curd nutrient recovery or whey loss traits predicted using Fourier-transform infrared spectroscopy of samples collected during milk recording on Holstein, Brown Swiss, and Simmental dairy cows. J. Dairy Sci. 98:4914-4927. https://doi.org/10.3168/jds.2014-8599.

Cipolat-Gotet, C., A. Cecchinato, G. Stocco, and G. Bittante. 2016. The 9-MilCA method as a rapid, partly automated protocol for simultaneously recording milk coagulation, curd firming, syneresis, cheese yield, and curd nutrients recovery or whey loss. J. Dairy Sci. 99:1065-1082. https://doi.org/10.3168/jds.2015-9734.

Clasen, J. B., A. Fogh, and M. Kargo. 2019. Differences between performance of $\mathrm{F} 1$ crossbreds and Holsteins at different production levels. J. Dairy Sci. 102:436-441. https://doi.org/10.3168/jds.2018 -14975 .

Dechow, C. D., and L. B. Hansen. 2017. Capitalizing breed differences and heterosis. Pages 369-378 in Large Dairy Herd Management. 3rd ed. American Dairy Science Association, Champaign, IL.

Dezetter, C., H. Leclerc, S. Mattalia, A. Barbat, D. Boichard, and V. Ducrocq. 2015. Inbreeding and crossbreeding parameters for production and fertility traits in Holstein, Montbéliarde, and Normande cows. J. Dairy Sci. 98:4904-4913. https://doi.org/10.3168/ jds.2014-8386.

Ezra, F., M. Van Straten, and J. I. Weller. 2016. Comparison of pure Holsteins to crossbred Holsteins with Norwegian Red cattle in first and second generations. Animal 10:1254-1262.

Hazel, A. R., B. J. Heins, and L. B. Hansen. 2017a. Fertility, survival, and conformation of Montbéliarde $\times$ Holstein and Viking Red $\times$ Holstein crossbred cows compared with pure Holstein cows during first lactation in 8 commercial dairy herds. J. Dairy Sci. 100:94479458. https://doi.org/10.3168/jds.2017-12824.

Hazel, A. R., B. J. Heins, and L. B. Hansen. 2017b. Production and calving traits of Montbeliarde $\times$ Holstein and Viking Red $\times$ Holstein cows compared with pure Holstein cows during first lactation in 8 commercial dairy herds. J. Dairy Sci. 100:4139-4149. https:// doi.org/10.3168/jds.2016-11860.

Hazel, A. R., B. J. Heins, A. J. Seykora, and L. B. Hansen. 2014. Production, fertility, survival, and body measurements of Montéliarde-sired crossbreds compared with pure Holsteins during their first 5 lactations. J. Dairy Sci. 97:2512-2525. https://doi.org/10 $.3168 /$ jds.2013-7063.

Heins, B. J., and L. B. Hansen. 2012. Short communication: Fertility, somatic cell score, and production of Normande $\times$ Holstein, Montbéliarde $\times$ Holstein, and Scandinavian Red $\times$ Holstein crossbreds versus pure Holsteins during their first 5 lactations. J. Dairy Sci. 95:918-924. https://doi.org/10.3168/jds.2011-4523.

International Dairy Federation. 2016. The world dairy situation. Bulletin 485/2016. International Dairy Federation, Brussels, Belgium.

Kargo, M., P. Madsen, and E. Norberg. 2012. Short communication: Is crossbreeding only beneficial in herds with low management level? J. Dairy Sci. 95:925-928. https://doi.org/10.3168/jds.2011-4707.

LIC. 2018. New Zealand dairy statistics 2017-2018. Accessed Sep. 10, 2019. https://www.lic.co.nz/about/dairy-statistics/.
Macheboeuf, D., J. B. Coulon, and P. D'Hour. 1993. Effect of breed, protein genetic variants and feeding on cow's milk coagulation properties. J. Dairy Res. 60:43-54. https://doi.org/10.1017/ S0022029900027333.

Malacarne, M., A. Summer, E. Fossa, P. Formaggioni, P. Franceschi, M. Pecorari, and P. Mariani. 2006. Composition, coagulation properties and Parmigiano-Reggiano cheese yield of Italian Brown and Italian Friesian herd milks. J. Dairy Res. 73:171-177. https://doi .org/10.1017/S0022029905001688.

Malchiodi, F., A. Cecchinato, and G. Bittante. 2014a. Fertility traits of purebred Holsteins and 2- and 3-breed crossbred heifers and cows obtained from Swedish Red, Montbéliarde, and Brown Swiss sires. J. Dairy Sci. 97:7916-7926. https://doi.org/10.3168/jds.2014 $-8156$.

Malchiodi, F., A. Cecchinato, M. Penasa, C. Cipolat-Gotet, and G. Bittante. 2014b. Milk quality, coagulation properties, and curd firmness modeling of purebred Holsteins and first- and secondgeneration crossbred cows from Swedish Red, Montéliarde, and Brown Swiss bulls. J. Dairy Sci. 97:4530-4541. https://doi.org/10 .3168/jds.2013-7868.

Martin, B., D. Pomiès, P. Pradel, I. Verdier-Metz, and B. Rémond. 2009. Yield and sensory properties of cheese made with milk from Holstein or Montbéliarde cows milked twice or once daily. J. Dairy Sci. 92:4730-4737. https://doi.org/10.3168/jds.2008-1914.

Maurmayr, A., S. Pegolo, F. Malchiodi, G. Bittante, and A. Cecchinato. 2018. Milk protein composition in purebred Holsteins and in first/second-generation crossbred cows from Swedish Red, Montbeliarde and Brown Swiss bulls. Animal 12:2214-2220. https://doi .org/10.1017/S1751731117003640.

Nilsson, K., H. Stålhammar, M. Stenholdt Hansen, H. LindmarkMånsson, S. Duchemin, F. Fikse, D. J. de Koning, M. Paulsson, and M. Glantz. 2019. Characterisation of non-coagulating milk and effects of milk composition and physical properties on rennetinduced coagulation in Swedish Red Dairy Cattle. Int. Dairy J. 95:50-57. https://doi.org/10.1016/j.idairyj.2019.03.006.

Penasa, M., N. López-Villalobos, R. D. Evans, A. R. Cromie, R. Dal Zotto, and M. Cassandro. 2010. Crossbreeding effects on milk yield traits and calving interval in spring calving dairy cows. J. Anim. Breed. Genet. 127:300-307. https://doi.org/10.1111/j.1439-0388 .2009.00840.x.

Poulsen, N. A., M. Glantz, A. K. Rosengaard, M. Paulsson, and L. B. Larsen. 2017. Comparison of milk protein composition and rennet coagulation properties in native Swedish dairy cow breeds and high-yielding Swedish Red cows. J. Dairy Sci. 100:8722-8734. https://doi.org/10.3168/jds.2017-12920.

Saha, S., L. Carraro, G. Bittante, and L. Gallo. 2018. Body and milk quality traits of purebred Holstein and three-generation crossbred cows from Viking Red, Montbéliarde and Holstein sires. J. Cent. Eur. Agric. 19:760-765. https://doi.org/10.5513/JCEA01/19.4 .2334 .

Shonka-Martin, B. N., A. R. Hazel, B. J. Heins, and L. B. Hansen. 2019a. Three-breed rotational crossbreds of Montbéliarde, Viking Red, and Holstein compared with Holstein cows for dry matter intake, body traits, and production. J. Dairy Sci. 102:871-882. https: //doi.org/10.3168/jds.2018-15318.

Shonka-Martin, B. N., B. J. Heins, and L. B. Hansen. 2019b. Threebreed rotational crossbreds of Montbéliarde, Viking Red, and Holstein compared with Holstein cows for feed efficiency, income over feed cost, and residual feed intake. J. Dairy Sci. 102:3661-3673. https://doi.org/10.3168/jds.2018-15682.

Skeie, S. 2007. Characteristics in milk influencing the cheese yield and cheese quality. J. Anim. Feed Sci. 16(Suppl. 1):130-142. https:// doi.org/10.22358/jafs/74164/2007.

Sørensen, M. K., E. Norberg, J. Pedersen, and L. G. Christensen. 2008. Invited review: Crossbreeding in dairy cattle: A Danish perspective. J. Dairy Sci. 91:4116-4128. https://doi.org/10.3168/jds.2008 $-1273$.

Stocco, G., C. Cipolat-Gotet, T. Bobbo, A. Cecchinato, and G. Bittante. 2017. Breed of cow and herd productivity affect milk com- 
position and modeling of coagulation, curd firming, and syneresis. J. Dairy Sci. 100:129-145. https://doi.org/10.3168/jds.2016-11662.

Stocco, G., C. Cipolat-Gotet, V. Gasparotto, A. Cecchinato, and G. Bittante. 2018. Breed of cow and herd productivity affect milk nutrient recovery in curd, and cheese yield, efficiency and daily production. Animal 12:434-444. https://doi.org/10.1017/ S1751731117001471.

Vance, E. R., C. P. Ferris, C. T. Elliott, S. A. McGettrick, and D. J. Kilpatrick. 2012. Food intake, milk production, and tissue changes of Holstein-Friesian and Jersey $\times$ Holstein-Friesian dairy cows within a medium-input grazing system and a high-input total confinement system. J. Dairy Sci. 95:1527-1544. https://doi.org/10 3168/jds.2011-4410.

VanRaden, P. M., J. B. Cole, and K. L. Parker Gaddis. 2018. Net merit as a measure of lifetime profit: 2018 revision. Accessed Nov. 8, 2018. https://aipl.arsusda.gov/reference/nmcalc-2018.htm.
Verdier-Metz, I., J. B. Coulon, P. Pradel, C. Viallon, and J. L. Berdagué. 1998. Effect of forage conservation (hay or silage) and cow breed on the coagulation properties of milks and on the characteristics of ripened cheeses. J. Dairy Res. 65:9-21. https://doi.org/10 .1017/s0022029997002616.

Weigel, K. A., and K. A. Barlass. 2003. Results of a producer survey regarding crossbreeding on US dairy farms. J. Dairy Sci. 86:4148 4154. https://doi.org/10.3168/jds.S0022-0302(03)74029-6.

\section{ORCIDS}

G. Bittante (ำ https://orcid.org/0000-0001-7137-7049

L. Gallo $\odot$ https://orcid.org/0000-0002-8908-5105 